\title{
ЗНАЧЕННЯ МОЛЕКУЛ СЕРЕДНЬОЇ МАСИ В ПРОГНОСТИЧНІЙ ОЦІНЦІ ЕТАНОЛОВОГО УШКОДЖЕННЯ ПЕЧІНКИ В ЩУРІВ ІЗ РІЗНОЮ ЕМОЦІЙНІСТЮ
}

\begin{abstract}
Значення молекул середньої маси в прогностичній оцінці етанолового ушкодження печінки в щурів із різною емоційністю
\end{abstract}

\section{О. А. Костюк, О. В. Денефріль}

Тернопільський національний медичний університет імені І. Я. Горбачевського мОЗ України

Резюме. Алкогольне ушкодження печінки є великим економічним та демографрічним тягарем у всьому світі. Одним із синдромів, який завжди супроводжує ушкодження печінки, $є$ ендогенна інтоксикація, наявність якої можна визначити за вмістом молекул середньоі маси (МСМ). Рівень МСМ залежить від метаболізму організму і є прогностичним критерієм порушення обмінних процесів.

Мета дослідження - визначити ступінь ендогенної інтоксикації за вмістом молекул середньої маси у сироватці крові щурів-самців із різним ступенем емоційності при етаноловому ушкодженні печінки.

Матеріали і методи. Досліди виконано на 192 білих безпородних високо- і низькоемоційних щурах-самцях (BE і HE). Емоційність тварин визначали за методом «відкрите поле». Усіх щурів поділили на наступні групи: контроль, глюкоза 7 днів, етаноловий гепатит (ЕГ); глюкоза 60 днів, етаноловий гепатоз (Гз), етаноловий фріброз (ЕФ), етаноловий цироз (ЕЦ). Рівень інтоксикації у сироватці крові визначали за вмістом молекул середньої маси при довжинах хвилі $\lambda=238$; 254; 260 і 280 нм.

Результати. Найбільше накопичення $\mathrm{MCM}_{238}$ було при ЕГз як у ВE, так і HE, а далі при ЕГ, більше виражено у НЕ, при ЕФ - у ВЕ і при ЕЦ незалежно від емоційності. Найбільше накопичення MCM $_{254}$ було при ЕГз, більше у ВE, далі при ЕГ незалежно від емоційності, при ЕЦ і ЕФ - у ВЕ та при ЕФ і ЕЦ - у НЕ. Найбільше накопичення $\mathrm{MCM}_{260}$ було при ЕГз, більше у ВE, далі при ЕЦ як у ВЕ, так і HЕ, при ЕФ, більше виражено у ВЕ та при ЕГ незалежно від емоційності. Найбільше накопичення $\mathrm{MCM}_{280}$ у BE тварин було в такому порядку $E \Gamma>E Ц>E \Phi=E \Gamma 3, y H E-E \Gamma>E Ц>E \Gamma 3>E \Phi$.

Висновки. Дослідження ендогенної інтоксикації за вмістом МСМ показало, що етанол має токсичний вплив на організм. Руйнування гепатоцитів зменшується в міру поглиблення патологічного процесу - від гепатозу до цирозу печінки. Залежність від емоційного стану тварини в розвитку етанолового (с)О. А. Костюк, О. В. Денефріль, 2020
Significance of middle mass molecules in prognosis assessment of ethanol liver damage in rats with different emotionality

\section{O. A. Kostiuk, O. V. Denefil}

I. Horbachevsky Ternopil National Medical University

e-mail: denefil@tdmu.edu.ua

Summary. Alcoholic liver damage is a major economic and demographic problem worldwide. One of the syndromes that always accompany liver damage is endogenous intoxication, the presence of which can be determined by the content of middle mass molecules (MMM). The level of MMM depends on the body's metabolism and is a prognostic criterion for metabolic disorders.

The aim of the study - to determine the degree of endogenous intoxication by the content of middle mass molecules in the serum of male rats with varying degrees of emotionality in ethanol liver damage.

Materials and Methods. The experiments were performed on 192 white outbred high- and low-emotional male rats (HE and $L E)$. The emotionality of rats was determined by the method of "open field". All rats were divided into the following groups: control, glucose 7 days, ethanol hepatitis (EG); glucose 60 days, ethanol hepatosis (EGs), ethanol fibrosis (EF), ethanol cirrhosis (EC). The level of intoxication in the serum was determined by the content of molecules of middle mass at wavelengths $\lambda=238,254,260$ and $280 \mathrm{~nm}$.

Results. The greatest accumulation of $M M_{238}$ was with EGs in both HE and LE, and then with EG, more dominant in $L E$, with EF - in HE and EC, regardless of emotionality. The greatest accumulation of $M_{M M} M_{254}$ was at EGs, more at $H E$, then at EG regardless of emotionality, at EC and EF - higher in HE and at EF and EC - higher in LE. The greatest accumulation of $\mathrm{MMM}_{260}$ was at EGs, more at $H E$, then at EC in both HE and LE, at EF, more at HE and at $E G$ regardless of emotionality. The largest accumulation of $M M_{280}$ in HE animals was in the following order EG> EC> $E F=\stackrel{280}{E}$ s, in $L E-E G>E C>E G s>E F$.

Conclusions. A study of endogenous intoxication on the content of MMM showed that ethanol has a toxic effect on the body. The destruction of hepatocytes decreases as the pathological process deepens from hepatosis to liver cirrhosis. Dependence on the emotional state of the animal in the development of ethanol damage to the body is manifested only in hepatitis and fibrosis. The largest accu- 
ушкодження організму проявляється тільки при гепатиті та фріброзі. Найбільше накопичення токсичних речовин наступне: у високоемоційних тварин гепатоз>гепатит>фріброз=цироз, у низькоемоційних - гепатит>гепатоз>фріброз>цироз.

Ключові слова: печінка, ендогенна інтоксикація; гепетит; цироз.

\section{ВСТУП}

Вживання алкоголю є великим економічним та демографрічним тягарем у всьому світі, оскільки спричинює хронічну патологію печінки, зокрема стеатоз, гепатит, фріброз, цироз і аденокарциному. $48 \%$ смертей у США у хворих на цироз печінки пов'язані 3 вживанням алкоголю [1]. Одним із синдромів, який завжди супроводжує ушкодження печінки, є ендогенна інтоксикація, наявність якої можна визначити за вмістом молекул середньої маси (МСM) [2, 3].

MCM є біохімічним маркером, що відображає рівень патологічного протеїнового метаболізму. Вони поділяються на дві великі групи - речовини середньої молекулярної маси та олігопептиди. Перша група є небілковими похідними різної природи, що накопичуються в організмі. Друга група, олігопептиди, є речовинами пептидної природи, які виконують регуляторні й нерегуляторні фрункції. Рівень МСМ залежить від метаболізму організму і $є$ прогностичним критерієм порушення обмінних процесів. Особливістю МСМ є їх висока біологічна активність. Накопичення їх $€$ не тільки маркером ендоінтоксикації, посилює перебіг патологічного процесу, набуваючи ролі вторинних токсинів, що впливають на життєдіяльність усіх систем і органів $[4,5]$.

Метою дослідження було визначити ступінь ендогенної інтоксикації за вмістом молекул середньої маси у сироватці крові щурів-самців з різним ступенем емоційності при етаноловому ушкодженні печінки.

\section{МАТЕРІАЛИ І МЕТОДИ}

Досліди виконано на 192 білих безпородних високо- і низькоемоційних щурах-самцях (BE і HЕ). В експеримент тварин брали у віці 3 місяці (усього методом «відкрите поле» протестовано 360 щурів).

Емоційність щурів визначали за методом «відкрите поле». Протягом 10 хв у камері «відкрите поле» визначали час виходу 3 першого квадрату, кількість пересічених квадратів, вертикальних стійок, заглядань у нірку, виходів у центр поля, чхань, реакцій грумінга, кількість уринацій, деорекацій, кількість болюсів. До високоемоційних (BE) тварин ми віднесли тих, в яких була висока горизонтальна і вертикальна активність, інтенсивне дослідження отворів у днищі тестової камери (нірок), нечасті завмирання. mulation of toxic substances is as follows: in highly emotional animals - hepatosis $>$ hepatitis $>$ fibrosis = cirrhosis, in low-emotional animals - hepatitis > hepatosis > fibrosis> cirrhosis.

Key words: liver; endogenous intoxication; hepatitis; cirrhosis.

I навпаки, до низькоемоційних (HЕ) віднесли тих, у яких була низька рухова активність, велика кількість завмирань і зростання їх тривалості, уникання тваринами центральних квадратів свідчить про високий рівень тривожності. При показниках М+33 \% тварин відносили до групи високоемоційних, М-33 \% - низькоемоційних). Тварин тестували двічі 3 інтервалом 14 днів. Відбирали для подальших досліджень щурів, які двічі підтвердили належність до високо- чи низькоемоційних, до моделювання патології мало пройти не менше 14 днів [6].

Усіх щурів поділили на наступні групи: контроль (К), глюкоза 7 днів (Гл7), етаноловий гепатит (ЕГ); глюкоза 60 днів (Гл60), етаноловий гепатоз (Гз), етаноловий фріброз (ЕФ), етаноловий цироз (ЕЦ).

Тварин групи контролю утримували в стандартних умовах віварію при вільному доступі до води та їжі.

Щури групи Гл7 перебували в стандартних умовах віварію при вільному доступі до їжі, але замість води для пиття отримували $5 \%$ розчин глюкози. Для моделювання ЕГ експериментальним тваринам вводили інтрагастрально 12,5 мл/кг $40 \%$ розчину етанолу на $5 \%$ глюкозі протягом 7 днів. Щури перебували в стандартних умовах віварію при вільному доступі до води та їжі [7].

Тварини групи Гл60 перебували в стандартних умовах віварію при вільному доступі до їжі, але замість води для пиття давали 5 \% розчин глюкози. Для моделювання ЕГз щурам вводили 60 днів $10 \%$ розчин етанолу на 5 \% розчині глюкозі як єдине джерело пиття (попередньо провівши звикання до етанолу 5 \% розчином етанолу на $5 \%$ розчині глюкози протягом 7 днів). Щури перебували в стандартних умовах віварію при вільному доступі до їжі [8]. Для моделювання ЕФ та ЕЦ попередньо проводили адаптацію до алкоголю: в перший тиждень тварини отримували в поїлках замість води $5 \%$ розчин етанолу, розбавлений на $5 \%$ розчині глюкози, на другий тиждень - 15 \% розчин етанолу, розбавлений 5 \% розчином глюкози без обмежень в їжі. Починаючи з третього тижня, була інтенсивна алкоголізація 96 \% розчином етанолу на шматочку білого хліба протягом 12 тижнів 14 г/кг (для ЕФ) та 18 г/кг маси (для ЕЦ) без обмежень у воді. Двічі на тиждень тваринам давали овес [9, 10]. Усім тваринам робили гістологічне дослідження печінки для підтвердження модельованої патології.
Вісник медичних і біологічних досліджень Bulletin of Medical and Biological Research
$4(6), 2020$ 
Усі експерименти проводили в першій половині дня в спеціально відведеному приміщенні при температурі $18-22^{\circ} \mathrm{C}$, відносній вологості 40-60 \% і освітленості 250 лк. Досліди виконано 3 дотриманням норм Конвенції Ради Європи про захист хребетних тварин, що використовуються для досліджень та інших наукових цілей (Страсбург, 1986), ухвали Першого національного конгресу 3 біоетики (Київ, 2001) і наказу МОЗ України № 690 від 23.09.2009 p.

Евтаназію щурів проводили шляхом тотального кровопускання з серця після попереднього тіопентал-натрієвого наркозу (60 мг·к $\Gamma^{-1}$ маси тіла тварини внутрішньочеревно). Рівень інтоксикації у сироватці крові визначали за вмістом молекул середньої маси при довжинах хвилі $\lambda=238 ; 254$; 260; 280 нм [4, 11]. Вираховували співвідношення $\mathrm{MCM}_{238} / \mathrm{MCM}_{260}$ - пептидно-нуклеїдний коесріцієнт (ПНКо), $\mathrm{MCM}_{238} / \mathrm{MCM}_{280}$ - коефіцієнт ароматичності (КоА), МCM $_{280} / \mathrm{MCM}_{254}$ - коесріцієнт розподілу
(КоР). Зменшення коефріцієнтів вказує на наростання ендогенної інтоксикації [12].

Статистичну обробку цифрових даних виконано за допомогою програмного забезпечення Excel (Microsoft, США) та STATISTICA 6.0 (Statsoft, США). Достовірність різниці значень між незалежними кількісними величинами визначали при нормальному розподілі за критерієм Стьюдента, в інших випадках - за допомогою непараметричних методів. Зміни вважали достовірними при $p \leq 0,05$. Відмінності між величинами вважали достовірними за вірогідності альтернативної гіпотези не менше ніж 0,95 [13].

\section{РЕЗУЛЬТАТИ Й ОБГОВОРЕННЯ}

При визначенні МСМ встановлено, що в контролі у ВЕ, порівняно з $\mathrm{HE}$, більші $\mathrm{MCM}_{238}$ у 2,3 раза $(p<0,001), M_{254}-$ на 64,2 \% ( $\left.p<0,001\right)$, ПНКо - y 5,8 раза $(p<0,001)$, КоА - 2,6 раза $(p<0,001)$, менші у 2,5 раза $(p<0,001) \mathrm{MCM}_{260}$, в 1,8 раза $(p<0,001)$ КоР (табл. 1). 3 отриманих даних випливає, що ви-

Таблиця 1. Зміни вмісту молекул середньої маси (од./л) у сироватці крові високо- та низькоемоційних щурів при розвитку етанолового гепатиту ( $\mathrm{M} \pm \mathrm{m}, \mathrm{n}=12)$

\begin{tabular}{|c|c|c|}
\hline \multirow{2}{*}{ Показник } & \multicolumn{2}{|c|}{ Група тварин } \\
\hline & високоемоційні & низькоемоційні \\
\hline \multicolumn{3}{|c|}{ Контроль } \\
\hline $\mathrm{MCM}_{238}$ & $0,282 \pm 0,005$ & $0,121 \pm 0,002^{* *}$ \\
\hline $\mathrm{MCM}_{254}$ & $0,365 \pm 0,008$ & $0,222 \pm 0,002^{* *}$ \\
\hline $\mathrm{MCM}_{260}$ & $0,107 \pm 0,001$ & $0,269 \pm 0,005^{* *}$ \\
\hline $\mathrm{MCM}_{280}$ & $0,163 \pm 0,007$ & $0,179 \pm 0,007$ \\
\hline $\mathrm{MCM}_{238} / \mathrm{MCM}_{260}$ & $2,63 \pm 0,05$ & $0,45 \pm 0,01^{\star *}$ \\
\hline $\mathrm{MCM}_{238} / \mathrm{MCM}_{280}$ & $1,78 \pm 0,10$ & $0,68 \pm 0,03^{* *}$ \\
\hline $\mathrm{MCM}_{280} / \mathrm{MCM}_{254}$ & $0,44 \pm 0,02$ & $0,81 \pm 0,03^{\text {*k }}$ \\
\hline \multicolumn{3}{|c|}{ Глюкоза, 7 днів } \\
\hline $\mathrm{MCM}_{238}$ & $0,340 \pm 0,003^{*}$ & $0,348 \pm 0,004^{*}$ \\
\hline $\mathrm{MCM}_{254}$ & $0,407 \pm 0,004^{*}$ & $0,402 \pm 0,005^{\star}$ \\
\hline $\mathrm{MCM}_{260}$ & $0,471 \pm 0,008^{*}$ & $0,430 \pm 0,009^{*, * *}$ \\
\hline $\mathrm{MCM}_{280}$ & $0,472 \pm 0,012^{*}$ & $0,498 \pm 0,009^{*}$ \\
\hline $\mathrm{MCM}_{238} / \mathrm{MCM}_{260}$ & $0,72 \pm 0,01^{*}$ & $0,81 \pm 0,02^{*, * *}$ \\
\hline $\mathrm{MCM}_{238} / \mathrm{MCM}_{280}$ & $0,72 \pm 0,02^{*}$ & $0,70 \pm 0,01$ \\
\hline $\mathrm{MCM}_{280} / \mathrm{MCM}_{254}$ & $1,16 \pm 0,03^{*}$ & $1,24 \pm 0,01^{*, * *}$ \\
\hline \multicolumn{3}{|c|}{ Етаноловий гепатит } \\
\hline $\mathrm{MCM}_{238}$ & $0,391 \pm 0,004^{*}, \#$ & $0,402 \pm 0,003^{*, * *, \#}$ \\
\hline $\mathrm{MCM}_{254}$ & $0,807 \pm 0,003^{*}, \#$ & $0,803 \pm 0,005^{*, \#}$ \\
\hline $\mathrm{MCM}_{260}$ & $0,503 \pm 0,005^{*}$,\# & $0,502 \pm 0,012^{*}, \#$ \\
\hline $\mathrm{MCM}_{280}$ & $1,018 \pm 0,011^{*}, \#$ & $0,959 \pm 0,003^{*, * *, \#}$ \\
\hline $\mathrm{MCM}_{238} / \mathrm{MCM}_{260}$ & $0,78 \pm 0,01^{*, \#}$ & $0,80 \pm 0,02^{*}$ \\
\hline $\mathrm{MCM}_{238} / \mathrm{MCM}_{280}$ & $0,38 \pm 0,01^{*, \#}$ & $0,42 \pm 0,01^{*, *,, \#}$ \\
\hline $\mathrm{MCM}_{280} / \mathrm{MCM}_{254}$ & $1,26 \pm 0,01^{*}, \#$ & $1,20 \pm 0,01^{*, * *, \#}$ \\
\hline
\end{tabular}

Примітки: 1) * - показники достовірні порівняно з контролем;

2) ** - показники достовірні порівняно з ВЕ;

3) \# - показники достовірні порівняно з глюкозою. 
сока емоційність пов'язана з більшим утворенням токсичних сполук, що може бути пов'язано з більшою руховою активністю і більшим апоптозом клітин, або з пониженою детоксикаційною функцією організму, зокрема печінки і нирок.

У групі Гл7 зросли всі досліджувані показники як у ВЕ, так і НЕ тварин. У ВЕ тварин збільшилися $\mathrm{MCM}_{238}$ - на 20,5\% (p<0,001), $\mathrm{MCM}_{254}$ - на 11,5\% $(p<0,001), M_{260}-$ в 4,4 раза $(p<0,001), M_{280}$ - в 2,9 раза ( $p<0,001)$. У НЕ щурів підвищилися $\mathrm{MCM}_{238}$ - у 2,9 раза ( $\left.\mathrm{p}<0,001\right), \mathrm{MCM}_{254}$ - на 80,8\% $(p<0,001), M_{260}-$ на $60 \%(p<0,001), M_{280}-y$ 2,8 раза $(\mathrm{p}<0,001)$. ПНКо у ВЕ тварин знизився у 3,6 раза $(p<0,001)$, КоA - у 2,5 раза $(p<0,001)$, КоР зріс у 2,6 раза ( $p<0,001)$. У НЕ щурів ПНКо зріс на $80,7 \%$ ( $<<0,001)$, КоР - на 53,7\% (p<0,001). При цьому МСМ 260 виявилися більшими у ВЕ, а ПНКо і КоР - у НЕ. Очевидно, що навантаження глюкозою спричинило ушкоджувальний ефект на клітини підшлункової залози і печінки, оскільки глюкоза не є складовою раціону щурів.

При ЕГ також зросли всі МСМ як у ВЕ, так і HE тварин. У ВЕ тварин збільшилися $\mathrm{MCM}_{238}-\mathrm{y}$ $3,4$ раза ( $p<0,001)$, MCM $_{254}-$ у 2,2 раза $(p<0,001)$, $\mathrm{MCM}_{260}$ - в 4,7 раза ( $\left.\mathrm{p}<0,001\right), \mathrm{MCM}_{280}$ - в 6,3 раза ( $p<0,001)$. У $\mathrm{HE}$ щурів підвищилися $\mathrm{MCM}_{238}-\mathrm{y}$ 3,3 раза $(p<0,001), \mathrm{MCM}_{254}-$ у 3,6 раза $(p<0,001)$, $\mathrm{MCM}_{260}$ - на $87 \%(\mathrm{p}<0,001), \mathrm{MCM}_{280}$ - у 2,4 раза $(p<0,001)$. ПНКо у ВЕ тварин знизився у 3,4 раза $(p<0,001)$, КоА - у 4,6 раза $(p<0,001)$, КоР зріс у $2,8$ раза ( $p<0,001)$. У НЕ щурів ПНКо зріс на 78,4 $\%(p<0,001)$, КоР - на 48,3 \% ( $<<0,001)$, КоА зменшився на 63,6 \% (p<0,001). При цьому MCM $_{238}$ і КоА виявилися більшими у НЕ, a $\mathrm{MCM}_{280}$ і KоP - у BE. 3 отриманих результатів випливає, що руйнування гепатоцитів відбувається однаковою мірою, але накопичення токсичних сполук більше у НЕ тварин, що очевидно пов'язано із сповільненим метаболізмом. Як видно з таблиці 1, у ВЕ і HЕ щурів зросли усі МСМ, порівняно з групою Гл7, що вказує на значний вплив етанолу на організм щурів. За розрахунковими показниками ендогенна інтоксикація як при дії етанолу, так і глюкози більше виражена у ВE щурів. Можливо вони чутливіші до ушкоджувальної дії етанолу за рахунок вищого основного обміну, а в результаті зростання. Токсичних впливів настає зрив адаптаційних механізмів.

У групі Гл60 у ВЕ збільшилися MCM $_{260}$ у 2,3 раза $(p<0,001), \mathrm{MCM}_{280}$ - у у 2,4 раза $(\mathrm{p}<0,001)$, КоР - 4,2 раза ( $p<0,001)$, зменшилися $\mathrm{MCM}_{238}$ у 2,4 раза ( $p<0,001)$, МCM $_{254}$ - на 43,9\% ( $\left.<<0,001\right)$, ПНКо - у 5,4 раза $(p<0,001)$, КоA - у 5,8 раза $(p<0,001)$ (табл. 2). У НЕ, навпаки, зросли $\mathrm{MCM}_{238}$ у 2,3 раза $(p<0,001), M_{254}-$ на 54,5\% $(p<0,001)$, ПНКо - у $5,1$ раза ( $<<0,001)$, КоА - в 2,4 раза $(p<0,001)$, а зменшилися $\mathrm{MCM}_{260}$ в 2,2 раза ( $\left.\mathrm{p}<0,001\right)$, КоР - на $64,5 \%$ ( $p<0,001)$. Виявилося, що $\mathrm{MCM}_{238}$ i $\mathrm{MCM}_{254}$,
ПНКо, КоА більші у НЕ, а $\mathrm{MCM}_{260}$ i $\mathrm{MCM}_{280}$, KoA - y BE. У цій групі тварин розвинувся неалкогольний стеатогепатоз, який більше виражений у ВЕ щурів. Видно, що руйнування гепатоцитів та інтоксикація організму у ВЕ тварин зменшується, а у НЕ тварин, навпаки, зросло руйнування гепатоцитів, накопичення токсичних речовин. Можна думати, що в зв'язку з підвищеним метаболізмом у ВЕ щурів стеатогепатоз розвинувся значно раніше, ніж у $\mathrm{HE}$ тварин, або у останніх, гепатит виникає раніше.

При аналізі змін МСМ при ЕГз виявлено їх зростання у ВЕ і НE, причому більші показники та менші коефіцієнти були у ВЕ. Так, у ВЕ тварин збільшилися MCM $_{238}$ - на 77,1\% ( $\left.<<0,001\right)$, $\mathrm{MCM}_{254}$ - y 2,3 раза ( $\left.<<0,001\right), \mathrm{MCM}_{260}-$ y 8,9 раза $(p<0,001), \mathrm{MCM}_{280}-$ y 3,9 раза $(p<0,001)$. У НЕ щурів підвищилися $\mathrm{MCM}_{238}$ - y 4,1 раза $(\mathrm{p}<0,001)$, $\mathrm{MCM}_{254}$ - у 3,2 раза (p<0,001), $\mathrm{MCM}_{260}-$ у 3,2 раза $(p<0,001), M_{280}-$ у 3,7 раза $(p<0,001)$. ПНКо у BE тварин знизився у 5 раз $(p<0,001)$, КоА - у 2,3 раза ( $<<0,001)$, КоР зріс на 69,4 \% (p<0,001). ПНКо у НЕ тварин зріс на 27,7 \% (p<0,001), КоР - на 17,7 $\%(p<0,001)$. Видно, що апоптоз гепатоцитів у тварин перебігає на одному рівні, але накопичення токсичних речовин більше у ВЕ тварин. Можна думати, що у зв'язку з підвищеним метаболізмом у BE щурів при етаноловому стеатогепатозі токсичні речовини не встигають елімінуватися. При порівнянні показників із групою Гл60, МСМ були більші при ЕГ, що вказує на значний вплив етанолу на організм щурів. За показниками коефіцієнтів ендогенна інтоксикація при дії етанолу і глюкози більша у HE, що може бути зумовлено вищою чутливістю до токсикантів.

При аналізі змін МСМ при ЕФ виявлено їх зростання у BE і HE, причому більші показники були у ВЕ. Так, у ВЕ тварин збільшилися МCM $_{254}$ - на 50,5 $\%(p<0,001), \mathrm{MCM}_{260}$ - y 5,7 раза ( $\left.\mathrm{p}<0,001\right), \mathrm{MCM}_{280}$ - у 3,9 раза ( $p<0,001)$. У НЕ щурів підвищилися $\mathrm{MCM}_{238}$ - y 2,1 раза ( $\left.\mathrm{p}<0,001\right), \mathrm{MCM}_{254}$ - y 2,5 раза $(p<0,001), M_{260}-$ у 2 рази $(p<0,001), M_{280}-y$ 2,9 раза $(p<0,001)$. ПНКо у ВЕ тварин знизився у 5,6 раза $(p<0,001)$, КоA - у 3,9 раза $(p<0,001)$, КоР зріс у 2,6 раза ( $<<0,001)$. КоА у НЕ тварин зріс на $41,7 \%(p<0,001)$, КоР - на 19,8 \% (p<0,001). У обох групах тварин, порівняно з попередніми патологіями, зменшується руйнування гепатоцитів, хоча у BE тварин воно залишається на вищому рівні. При порівнянні показників із групою Гл60, МСМ були більші при ЕФ, що вказує на значний вплив етанолу на організм щурів. За показниками коефіцієнтів ендогенна інтоксикація при дії етанолу і глюкози більша у НЕ. Отримані дані підтверджують попередні, що недивлячись на більше ушкодження у $\mathrm{BE}$ особин, чутливішими $€ \mathrm{HE}$ щури.

При аналізі змін МСМ при ЕЦ виявлено їх зростання у ВЕ і НЕ, причому показники майже не відріз- 
Таблиця 2. Зміни вмісту молекул середньої маси в сироватці крові високо- та низькоемоційних щурів при розвитку ушкодження печінки етанолом (M $\pm \mathrm{m}, \mathrm{n}=12)$

\begin{tabular}{|c|c|c|}
\hline \multirow{2}{*}{ Показник } & \multicolumn{2}{|c|}{ Група тварин } \\
\hline & високоемоційні & низькоемоційні \\
\hline \multicolumn{3}{|c|}{ Контроль } \\
\hline $\mathrm{MCM}_{238}$ & $0,282 \pm 0,005$ & $0,121 \pm 0,002^{* *}$ \\
\hline $\mathrm{MCM}_{254}$ & $0,365 \pm 0,008$ & $0,222 \pm 0,002^{* *}$ \\
\hline $\mathrm{MCM}_{260}$ & $0,107 \pm 0,001$ & $0,269 \pm 0,005^{\star \star}$ \\
\hline $\mathrm{MCM}_{280}$ & $0,163 \pm 0,007$ & $0,179 \pm 0,007$ \\
\hline $\mathrm{MCM}_{238} / \mathrm{MCM}_{260}$ & $2,63 \pm 0,05$ & $0,45 \pm 0,01^{* *}$ \\
\hline $\mathrm{MCM}_{238} / \mathrm{MCM}_{280}$ & $1,78 \pm 0,10$ & $0,68 \pm 0,03^{* *}$ \\
\hline $\mathrm{MCM}_{280} / \mathrm{MCM}_{254}$ & $0,44 \pm 0,02$ & $0,81 \pm 0,03^{* *}$ \\
\hline \multicolumn{3}{|c|}{ Глюкоза, 60 днів } \\
\hline $\mathrm{MCM}_{238}$ & $0,118 \pm 0,002^{*}$ & $0,275 \pm 0,004^{*, * *}$ \\
\hline $\mathrm{MCM}_{254}$ & $0,208 \pm 0,005^{\star}$ & $0,343 \pm 0,007^{\star, * \star}$ \\
\hline $\mathrm{MCM}_{260}$ & $0,244 \pm 0,006^{*}$ & $0,120 \pm 0,002^{*, * *}$ \\
\hline $\mathrm{MCM}_{280}$ & $0,383 \pm 0,007^{*}$ & $0,167 \pm 0,004^{\star *}$ \\
\hline $\mathrm{MCM}_{238} / \mathrm{MCM}_{260}$ & $0,49 \pm 0,01^{*}$ & $2,31 \pm 0,05^{*, * *}$ \\
\hline $\mathrm{MCM}_{238} / \mathrm{MCM}_{280}$ & $0,31 \pm 0,01^{*}$ & $1,66 \pm 0,05^{*, * *}$ \\
\hline $\mathrm{MCM}_{280} / \mathrm{MCM}_{254}$ & $1,86 \pm 0,06^{*}$ & $0,49 \pm 0,02^{* * *}$ \\
\hline \multicolumn{3}{|c|}{ Етаноловий гепатоз } \\
\hline $\mathrm{MCM}_{238}$ & $0,500 \pm 0,010^{*}, \#$ & $0,500 \pm 0,015^{\star, \#}$ \\
\hline $\mathrm{MCM}_{254}$ & $0,848 \pm 0,005^{*}, \#$ & $0,709 \pm 0,021_{, *,, \#}^{*, \#}$ \\
\hline $\mathrm{MCM}_{260}$ & $0,957 \pm 0,005^{*}, \#$ & $0,870 \pm 0,009^{*, * *, \#}$ \\
\hline $\mathrm{MCM}_{280}$ & $0,640 \pm 0,009^{*}, \#$ & $0,668 \pm 0,011^{*}, \#$ \\
\hline $\mathrm{MCM}_{238} / \mathrm{MCM}_{260}$ & $0,52 \pm 0,01^{*}$ & $0,57 \pm 0,02^{*, * *, \#}$ \\
\hline $\mathrm{MCM}_{238} / \mathrm{MCM}_{280}$ & $0,78 \pm 0,02^{*}, \#$ & $0,75 \pm 0,02^{\#}$ \\
\hline $\mathrm{MCM}_{280} / \mathrm{MCM}_{254}$ & $0,75 \pm 0,01^{*, \#}$ & $0,95 \pm 0,03^{\star, * \star, \#}$ \\
\hline \multicolumn{3}{|c|}{ Етаноловий фріброз } \\
\hline $\mathrm{MCM}_{238}$ & $0,288 \pm 0,005^{\#, \# \#}$ & $0,254 \pm 0,010^{*, * *, \# \#}$ \\
\hline $\mathrm{MCM}_{254}$ & $0,549 \pm 0,010^{*}, \#, \# \#$ & $0,548 \pm 0,015^{\star}, \#, \# \#$ \\
\hline $\mathrm{MCM}_{260}$ & 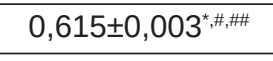 & 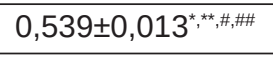 \\
\hline $\mathrm{MCM}_{280}$ & $0,639 \pm 0,008^{*, \#}$ & 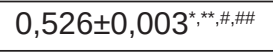 \\
\hline $\mathrm{MCM}_{238} / \mathrm{MCM}_{260}$ & $0,47 \pm 0,01^{*}, \# \#$ & $0,47 \pm 0,02^{\#, \# \#}$ \\
\hline $\mathrm{MCM}_{238} / \mathrm{MCM}_{280}$ & 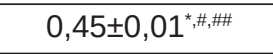 & 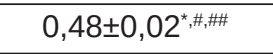 \\
\hline $\mathrm{MCM}_{280} / \mathrm{MCM}_{254}$ & $1,17 \pm 0,02^{*}, \#, \#$ & 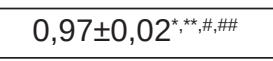 \\
\hline \multicolumn{3}{|c|}{ Етаноловий цироз } \\
\hline $\mathrm{MCM}_{238}$ & $0,210 \pm 0,004^{*}, \#, \#, \&$ & 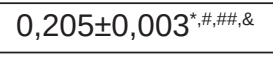 \\
\hline $\mathrm{MCM}_{254}$ & $0,573 \pm 0,017^{*}, \# \#$ & 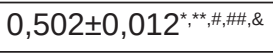 \\
\hline $\mathrm{MCM}_{260}$ & $0,749 \pm 0,024^{*}, \#, \#, \&$ & $0,759 \pm 0,031^{*}, \#, \#, \&$ \\
\hline $\mathrm{MCM}_{280}$ & $0,932 \pm 0,011^{*}, \#, \#, \&$ & $0,924 \pm 0,008^{*, \#, \# \#, \&}$ \\
\hline $\mathrm{MCM}_{238} / \mathrm{MCM}_{260}$ & $0,28 \pm 0,01^{*}, \#, \# \#, \&$ & $0,27 \pm 0,01^{*}, \#, \#, \&$ \\
\hline $\mathrm{MCM}_{238} / \mathrm{MCM}_{280}$ & $0,23 \pm 0,01^{*}, \#, \# \#, \&$ & $0,22 \pm 0,01^{*}, \#, \# \#, \&$ \\
\hline $\mathrm{MCM}_{280} / \mathrm{MCM}_{254}$ & $1,64 \pm 0,05^{*, \#, \# \#, \&}$ & 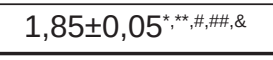 \\
\hline
\end{tabular}

Примітки: 1) * - показники достовірні порівняно з контролем;

2) ** - показники достовірні порівняно з ВЕ;

3) \# - показники достовірні порівняно з глюкозою;

4) \#\# - показники достовірні порівняно з гепатозом

5) \& - показники достовірні порівняно з фріброзом. 
нялися (за винятком МСM $_{254}$ ). Так, у ВЕ тварин зменшилися $\mathrm{MCM}_{238}$ - на 34,5\% (p<0,001), збільшилися $\mathrm{MCM}_{254}$ - на 57\% ( $\left.<<0,001\right)$, MCM $_{260}$ - у 7 разів $(p<0,001), \mathrm{MCM}_{280}-$ y 5,7 раза $(p<0,001)$. У HE щурів підвищилися $\mathrm{MCM}_{238}$ - на $70 \%$ ( $\left.<<0,001\right)$, $\mathrm{MCM}_{254}$ - у 2,3 раза ( $\left.<<0,001\right), \mathrm{MCM}_{260}$ - у 2,8 раза $(p<0,001), M_{280}$ - у 5,2 раза $(p<0,001)$. ПНКо у ВЕ тварин знизився у 9,3 раза ( $<<0,001)$, КоА - у 7,9 раза (p<0,001), КоР зріс у 3,7 раза $(p<0,001)$. ПНКо у НЕ тварин зменшився на 64,3 \% (p<0,001), КоА - у 3,1 раза ( $p<0,001)$, КоР збільшився у 2,3 раза $(p<0,001)$. І знов бачимо припинення руйнування клітин у ВE, і продовження патологічного процесу в HЕ. У ВЕ тварин продовжують накопичуватися токсичні продукти. При порівнянні показників із групою Гл60, МСМ були більші при ЕЦ (крім $\mathrm{MCM}_{238}$ ), що вказує на значний вплив етанолу на організм щурів. За показниками коефіцієнтів ендогенна інтоксикація при дії етанолу і глюкози більша у НЕ. Зміни МСМ при ЕЦ, порівняно з ЕГз, більші при гепатозі (за винятком MCM $_{280}$ ), а ендогенна інтоксикація більш виражена за значеннями коефіцієнтів при ЕЦ. Зміни МСМ при ЕЦ, порівняно з ЕФ, більші при цирозі (за показниками $\mathrm{MCM}_{260}$ i $\mathrm{MCM}_{280}$ ), та й ендогенна інтоксикація більш виражена ніж значення коеоріцієнтів (крім КоР) при ЕЦ.

Відомо, що фрракція МСМ $_{280}$ складається 3 нетоксичних ароматичних амінокислот, а MCM $_{254}$ містять токсичні речовин, збільшення нуклеарної

\section{СПИСОК ЛІТЕРАТУРИ}

1. ACG Clinical Guideline: Alcoholic Liver Disease I A. K. Singal, R. Bataller, J. Ahn [et al.] // American Journal of Gastroenterology. - 2018. - Vol. 113 (2). - P. 175-194.

2. Fiedorova A. A. Indicators of endogenous intoxication and detoxification system of erythrocytes in acute burn injury / A. A. Fiedorova, B. H. Borzenko // The issue of Experimental and Clinical Medicine. - 2010. - No. 2 (14). - P. 343-347.

3. Показники молекул середньої маси як критерій об'єктивної оцінки якості життя хворих на гостру мієлоїдну лейкемію / М. Ю. Аношина, Н.В.Горяінова, В. О. Кубарова, О. В. Басова // J. Clin. Exp. Med. Res. 2015. - № 3(2). - C. 223-230.

4. Бондаренко В. В. Молекули середньої маси в тканинах слинних залоз при експериментальній опіковій хворобі / В. В. Бондаренко, Л. Г. Нетюхайло, Д. С. Аветіков // Таврический медико-биологический вестник. - 2012. - Т. 15, № 3, ч. 1 (59). - С. 49-50.

5. Вміст молекул середньої маси та олігопептидів у крові та тканинах щурів за умов розвитку кислотного опіку стравоходу / Т. В. Коваль, Т. В. Іщук, Я. Б. Раєцька [та ін.] // Біологічні системи. - 2015. - Т. 7, вип. 2. - С. 143-148.

6. Лукьянова Л. В. Изучение поведенческих реакций при введении кофеина, карбмазепина и их композиций в условиях формалинового отёка у крыс / Л. В. Лукьянова // Український біофрармацевтичний журнал. - 2016. - Т. 42, № 1. - C. 22-26.

7. Пат. № 135341 МПК: G 09 В 23/28. Спосіб моделювання гострого етанолового гепатиту у високоемо- фрракції $\mathrm{MCM}_{238}$ пов'язано із апоптичним руйнуванням клітин. Виходячи $з$ цього, видно, що апоптоз зменшується в міру поглиблення патологічного процесу - ЕГз>ЕГ>ЕФ>ЕЦ. Причому тільки при ЕГ виявлено більші зміни у НЕ, а при ЕФ - у ВЕ. Найбільше накопичення токсичних речовин наступне: у $\mathrm{BE}-\mathrm{E} Г$ З $>\mathrm{E} Г>\mathrm{E}=Е Ц$, у НЕ - ЕГ>ЕГз>ЕФ>ЕЦ. Очевидно, що руйнування гепатоцитів зменшується у міру прогресування патологічного процесу. Накопичення токсичних речовин у ВЕ тварин зменшується у міру прогресування патологічного процесу, а в НЕ щурів гепатит є тяжчим. Екскреторна фрункція нирок зменшена (за накопиченям $\mathrm{MCM}_{280}$ ) при гепатиті та цирозі печінки, що пов'язано з активністю патологічного процесу при гепатиті та поліорганними порушеннями при цирозі.

\section{ВИСНОВКИ}

Дослідження ендогенної інтоксикації за вмістом МСМ показало, що етанол має токсичний вплив на організм. Руйнування гепатоцитів зменшується в міру поглиблення патологічного процесу - від гепатозу до цирозу печінки. Залежність від емоційного стану тварини в розвитку етанолового ушкодження організму проявляється тільки при гепатиті та фріброзі. Найбільше накопичення токсичних речовин наступне: у високоемоційних тварин - гепатоз>гепатит>фріброз=цироз, у низькоемоційних - гепатит>гепатоз>оріброз>цироз.

ційних та низькоемоційних щурів-самців / Костюк О. А., Денесіль О. В., Головата Т. К. - опубл. 25.06.2019, Бюл. 12/2019.

8. Пат. № 135342 МПК: G 09 В 23/28. Спосіб моделювання хронічного етанолового гепатозу у високоемоційних та низькоемоційних щурів-самців / Костюк О. А., Денефіль О. В., Головата Т. К. - опубл. 25.06.2019, Бюл. 12/2019.

9. Пат. № 135948 МПК: G 09 В 23/28. Спосіб моделювання етанолового цирозу у високоемоційних та низькоемоційних щурів-самців / Костюк О. А., Денефіль О. В., Головата Т. К. - опубл. 25.07.2019, Бюл. 14/2019.

10. Пат. № 135949 МПК: G 09 В 23/28. Спосіб моделювання етанолового фріброзу у високоемоційних та низькоемоційних щурів-самців / Костюк О. А., Денефріль О. В., Головата Т. К. - опубл. 25.07.2019, Бюл. 14/2019.

11. A review of recent studies on malondialdehyde as toxic molecule and biological marker of oxidative stress / D. Del Rio, A. J. Stewart, N. Pellegrini // Nutr. Metab. Cardiovasc. Dis. - 2005. - Vol. 15 (4). - P. 316-328.

12. Макаренко Т. М. Співвідношення біохімічних показників крові в медичній практиці: клініко-діагностичне значення / Т. М. Макаренко, О. М. Радченко // Практикуючий лікар. - 2017. - Т. 6 (2). - С. 49-53.

13. Лапач С. Н. Статистические методы в медикобиологических исследованиях с использованием Excel / С. Н. Лапач, А. В. Чубенко, П. Н. Бабич. - К. : Морион, 2000. -320 c. 


\section{REFERENCES}

1. Singal AK, Bataller R, Ahn J, Kamath PS, Shah VH. ACG Clinical Guideline: Alcoholic Liver Disease. American Journal of Gastroenterology. 2018;113(2): 175-94.

2. Fiedorova $A A$, Borzenko $B H$. Indicators of endogenous intoxication and detoxification system of erythrocytes in acute burn injury. The issue of Experimental and Clinical Medicine. 2010;2(14): 343-7.

3. Anoshina MYu, Horyainova NV, Kubarova VO, Basova OV. [Indicators of molecules of average mass as a criterion for objective assessment of the quality of life of patients with acute myeloid leukemia]. J Clin Exp Med Res. 2015;3(2): 223-30. Ukrainian.

4. Bondarenko VV, Netyukhaylo LG, Avetikov DS. [Mean mass moleculas in tissues of salivary glands in result of experimental burn disease]. Tavricheskiy medikobiologicheskiy vestnik. 2012;15(3)1(59): 49-50. Ukrainian.

5. Koval TV, Ishchuk TV, Raetska YaB, Savchuk OM, Ostapchenko LI. [The content of middle mass molecules and oligopeptides in the blood and tissues of rats under conditions of acid burn of the esophagus]. Biolohichni systemy. 2015;7(2): 143-8. Ukrainian.

6. Lukyanova LV. [Study of behavioral reactions with the introduction of caffeine, carbmazepine and their compositions under conditions of formalin edema in rats]. Ukrainskyi biofarmatsevtychnyi zhurnal. 2016;42(1): 22-6. Russian.

7. Kostyuk OA, Denefil OV, Holovata TK. Patent No. 135341 IPC: G 09 B 23/28; [Method for modeling acute ethanol hepatitis in highly emotional and low-emotional male rats]. Published on June 25, 2019, Bull. 12/2019. Ukrainian.

8. Kostyuk OA, Denefil OV, Holovata TK. Patent No. 135342 IPC: G 09 B 23/28; [Method for modeling chronic ethanol hepatosis in highly emotional and low-emotional male rats]. Published on June 25, 2019, Bull. 12/2019. Ukrainian.

9. Kostyuk OA, Denefil OV, Holovata TK. Patent No. 135948 IPC: G 09 B 23/28; [Method of modeling ethanol cirrhosis in highly emotional and low-emotional male rats]. Published on July 25, 2019, Bull. 14/2019. Ukrainian.

10. Kostyuk OA, Denefil OV, Holovata TK. Patent № 135949 IPC: G 09 B 23/28; [Method of modeling ethanol fibrosis in highly emotional and low-emotional male rats]. Published on July 25, 2019, Bull. 14/2019. Ukrainian.

11. Del Rio D, Stewart AJ, Pellegrini N. A review of recent studies on malondialdehyde as toxic molecule and biological marker of oxidative stress. Nutr Metab Cardiovasc Dis. 2005;15(4): 316-28.

12. Makarenko TM, Radchenko OM. [The ratio of biochemical parameters of blood in medical practice: clinical and diagnostic value]. Praktykuiuchyi likar. 2017;6(2): 4953. Ukrainian

13. Lapach SN, Chubenko AV, Babich PN. Statistical methods in biomedical research using Excel. Kyiv: Morion; 2000. Russian. 